\title{
Geothermal Energy with Heat Pump as a Possible Solution in Dramatic Climate Change - Market Situation and Potential in Germany of a Renewable Energy Source
}

\author{
David Novak \\ Engerode 56, D 30880 Laatzen, Germany \\ Received May 5, 2019; Revised October 15, 2019; Accepted October 30, 2019
}

Copyright $@ 2020$ by authors, all rights reserved. Authors agree that this article remains permanently open access under the terms of the Creative Commons Attribution License 4.0 International License

\begin{abstract}
Goal: Global sustainability is becoming an increasingly important topic, which is impressively demonstrated by numerous conferences of the UN and its sister organizations with worldwide participation. The purpose of this paper is to critically review the use of geothermal energy through the use of heat pumps. Opportunities and starting points are discussed briefly. Design / Methodology / Approach: This paper does not only deal with geothermal energy, but also shows the potential uses and effects of using heat pumps. Not only the basic assumptions and the goals are documented, but these are, as far as possible, checked for their realism or feasibility. Carry out a method comparison of the published literature with technical, economic and ecological approaches. Findings: The findings are presented in a concise summary and provide opportunities for further analysis, discussion or results. The use of heat pumps to reduce $\mathrm{CO}_{2}$ emissions in heat production, to measure the impact on nature using indicators and values. Geothermal energy can make a significant contribution to environmental protection through the use of heat pumps. Their lack of market penetration in Germany is apparently not due to too low benefits, but rather to lack of awareness (lack of marketing) and also lack of German government support, e.g. about tax incentives. Research / Practical Implications: Results and implications for practice, applications and consequences are identified. Use of geothermal energy and its effects can be assessed in the short, medium and long term. All people worldwide could use geothermal energy if they had a working electrical connection. Future research into renewable energy sources should always include geothermal energy, although currently it does not have enough multipliers and interest groups to support it. From the perspective of permanent
\end{abstract}

availability (24/7), it is unbeatable. Originality / Value: This paper deals with sustainability and the related consequences in the field of regenerative energy production through the use of geothermal heat, as well as the implementation by means of heat pumps. In addition to purely scientific literature, facts and figures are used by the German Federal Environment Agency and the German Federal Ministry of Economics and Technology, which ensure the highest degree of neutrality.

Keywords Renewable Energy Production, Geothermal Energy, Heat Pumps, $\mathrm{CO}_{2}$ Reduction

JEL Codes: O13, Q01, Q42, Q54, Q55

\section{Introduction - Utilization of Existing Geothermal Energy (Geothermal Energy)}

Currently, there is a lot of talk about regenerative energy generation, which mostly focuses on power generation. The generation of heat is not the focus here, and it is precisely the envisaged energy transition that essentially depends on this energy range. The Fraunhofer Institute sees geothermal energy as a good solution, which can be used with heat pumps (Fraunhofer IWES / IBP, 2012). These heat pumps can generate both less power, as well as much larger heat. The already existing amount of energy of the geothermal energy is practically inexhaustible and also compared to wind and sun, permanent and really 24/7, available. This makes them a real solution for the necessary conversion to a world with renewable energy supply. 
According to the U.S. American report of "U.S. Global Change" (US Global Change Research Program) is expected by the end of this century with hundreds of thousands of deaths and annual costs up to 1 trillion US dollars by climate change. For this reason too, pro-active action is already compelling today, as the consequences of human action, including the positive ones, will only have an ecological impact in the medium term.

This paper is largely based on German sources or the prevailing perspective in Germany, both from a technological, as well as economic and socio-political point of view, which may differ from other states partially or even significantly. A common and consistent view of the world obviously does not exist for a variety of reasons.

\section{Technical Basics of the Heat Pump}

A heat pump is a machine that utilizes thermal energy from a reservoir at a lower temperature (usually the surrounding environment) and, together with the drive energy, using heat as a useful heat to heat a system to be heated with higher temperature (space heating) transmits. The process used is in principle the reversal of a heat-power process, in which heat energy is taken up at high temperature and partly converted into mechanical work and the residual energy is dissipated at lower temperature than waste heat, usually to the environment. The principle of the heat pump is based on the thermodynamic cycle, in which a heat transfer medium circulates in different states of aggregation. At certain temperatures and pressures, this medium vaporizes and can be used accordingly for heating and power generation. If it is designed accordingly, it can also be used in the opposite direction for cooling, with only heat and electricity generation being treated below (Miara et al, 2013).

The amount of heat transferred to the heating circuit is the sum of the mechanical energy supplied by the compressor used and the absorbed thermal energy in the evaporator (Ast, 2012).

As a medium from which heat is extracted, both the outer ambient air, water in larger bodies of water or as groundwater and finally the soil can serve. However, it should be noted in advance how long this heat source with a certain minimum temperature is available in order to be as long-term as possible. As the amount of heat that is constantly and permanently available increases the deeper one drills, it automatically leads to a trend of deep drilling if surface water and air do not provide sufficient heat permanently (Tiator, 2014).

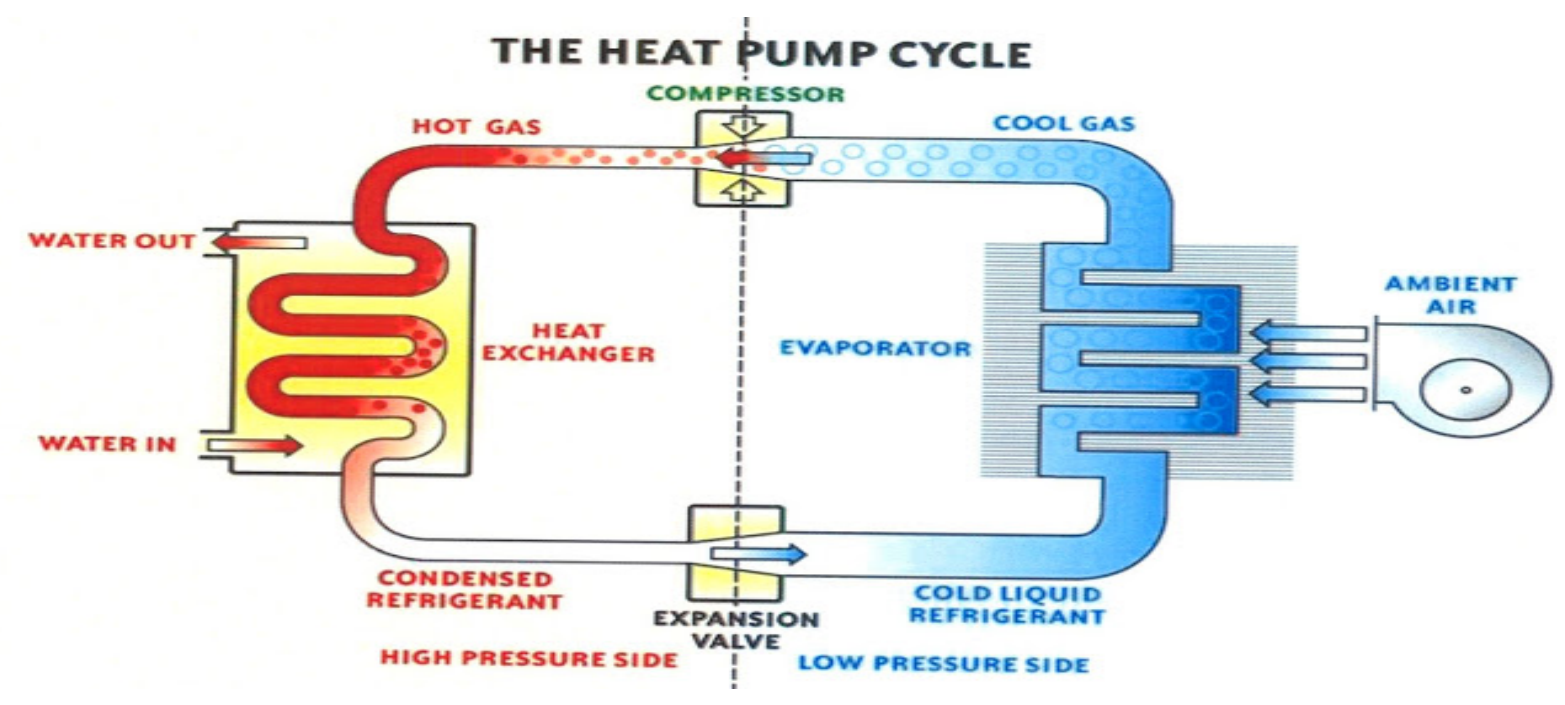

Source: Mech-Engineering

Figure 1. The heat pump cycle 


\section{Economic Basics of the Heat Pump}

The economic consideration of the use of a heat pump is ultimately decisive whether this is used, because for the user, it should indeed be financially worthwhile. The quotient between the electrical power of the compressor and the heat output of the condenser shows how efficiently the heat pump works. This ratio is referred to as the COP value (coefficient of performance). The COP value applies only to the heat pump and not to the complete heating system of a building. Also crucial is the so-called "annual work figure", which results from the use of the heat source and the heat pump system. It is simply about how much electrical energy you have to supply the heat pump and how much heat energy on the other hand he keeps. The higher the number, the more efficient and ultimately more economical the system is. There is no ultimate maximum in efficiency (Miara, et al, 2013).

\section{Geothermal Energy from a Technical Point of View}

In the case of near-surface geothermal energy, the use of geothermal energy is described down to a depth of $400 \mathrm{~m}$, whereby drilling is usually only to a depth of approx. 150 $\mathrm{m}$. Here there are massive differences between the layers of the earth and their respective heat conditions. The target areas are those that permanently have a temperature of approx. 20 degrees Celsius and can therefore be used efficiently. Ultimately it is irrelevant whether you use geothermal collectors, geothermal probes, geothermal wells or geothermal piles - crucial is really only the long-term usability and the associated technical difficulties or the resulting costs.

In addition, there are systems of deep geothermal energy, the heat from 5,000 - 7,000 $\mathrm{m}$ depth, where there is often a temperature of up to 200 degrees Celsius. They run under different names such as hot-dry-rock and hot-fractured-rock-system. These systems require solid financial foundations and are therefore meaningful only for large plants, but have the great advantage that the amount of heat available at this depth for a very long time usable, at least much longer than the near-surface drilling (Stober, Bucher, 2014).

The underground, which can already be developed with today's technical means, provides an energy reserve that can sustainably secure the entire global energy requirement for hundreds of years. The limitation lies not in the amount of geothermal energy available, but in the cost-effectiveness of the different development techniques and thus in the overall package itself. Geothermal energy is also a regenerative resource in Germany, as everywhere else in the world. The usable energy reserve - which can be developed with today's deep drilling technology - is estimated to be around 30 times all fossil reserves (coal, gas and oil) worldwide. Due to the quantities that can be exploited in the future, the geothermal reserve can be considered practically inexhaustible. The heat in the Earth's interior is the engine that has been shifting continents for over 4 billion years, piling up all the mountains in the world and causing volcanoes to spew. Natural radioactive decay processes in the Earth's interior have been maintaining the temperature for billions of years (Bundesverband Geothermie, online).

\section{TOP 10 GEOTHERMAL COUNTRIES}

INSTALLED CAPACITY - MW (JANUARY 2018) - 14,060 MW IN TOTAL
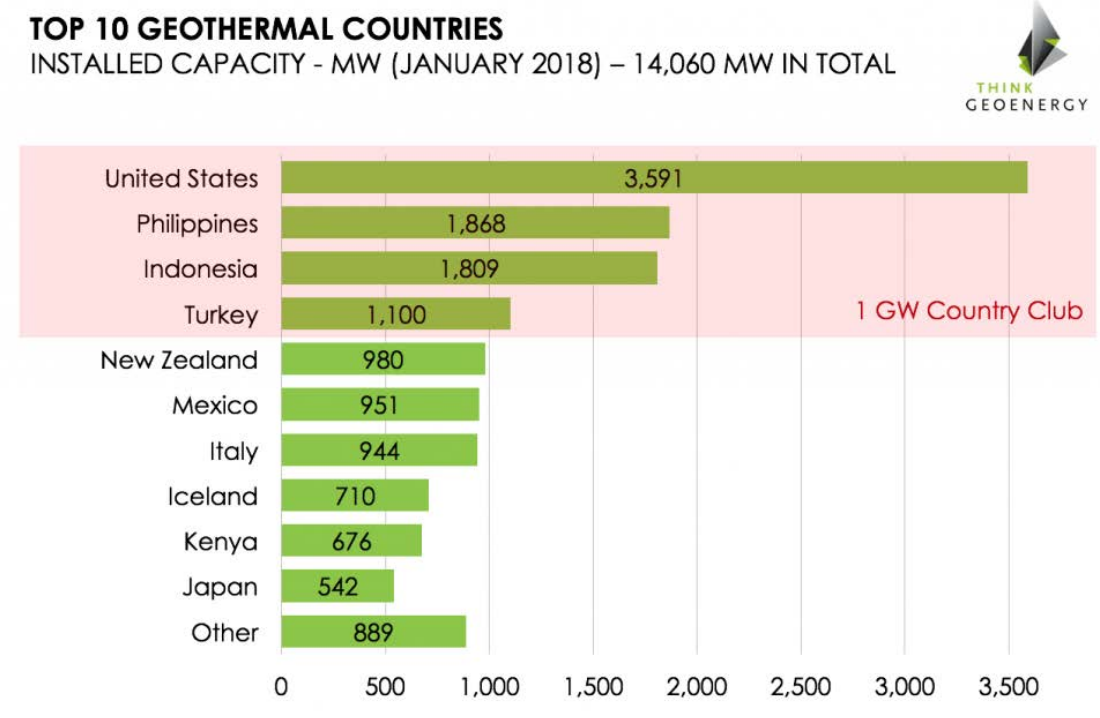

Source: TGE Research (2017), GEA (2016), IGA (2015), JESDER (2017) Enerii Atlasi (2017)

Source: Richter, A., Thin Geo Energy

Figure 2. Installed geothermal capacity by countries in 2018 
The global use of geothermal energy, as shown in the diagram above, can be misleading because it only represents the total installed capacity, but it is not divided into electricity and heat generation. Nonetheless, it is obvious that states such as the US, the Philippines, Indonesia, Mexico or Turkey, which are not well known for environmental protection and renewable energy, are clearly pioneers in the use of geothermal energy. The reasons for this very different international distribution can be very different and need not necessarily be transferable from one state to the next. For example, relatively high outdoor or water temperatures in winter, as well as warm underground sources are good reasons for an efficient and affordable use of geothermal energy. (RealClearEnergy, online, 2014). Germany, which is considered to be the world leader in the use of renewable energies, only appears under "Other" in this form of energy generation.

\section{Geothermal Energy from an Economic and Political-Sociological Point of View}

If one looks at the share of geothermal energy in the world's energy production, and summarizes this combined with other smaller energy sources just $0.4 \%$, then it must be clear that geothermal status today plays absolutely no relevant role in power generation. This must be a massive surprise for two reasons: first, this power generation is absolutely clean and causes, e.g. in comparison to the production of solar cells, practically no waste or wastewater, on the other hand it is available $24 \times 7$ and does not depend on random events such as wind force and insolation, but is permanent and surplus energy does not need to be stored. Even in Germany, a country that leads the world in regenerative energy use, the market share of heat produced for buildings (heat produced here, not electricity as shown above) is heat pumped Currently part of the energy market) at approx. 8.6\% with 14.7 TWh (Umweltbundesamt, online). This is all the more remarkable as a full-cost heat pump falls well short of most other energy sources. Only gas-fired condensing boilers are significantly cheaper (Leipziger Institut, 2012). But they are not renewable in their energy production and produce exhaust gases such as $\mathrm{CO}^{2}$.

The use of heat pumps and geothermal energy are not subject to any obvious acceptance problems in the German population. The benefits to the environment and sustainability are largely acknowledged in society, though perhaps not always conscious. In addition to the advantages already mentioned, the low level of noise pollution and the production directly on site also mean that virtually any transportation costs are eliminated or at least minimized. The only disadvantages are the necessary drilling and the associated legal requirements and costs, if the use of air and surface water is not possible (Freeden, 2018).

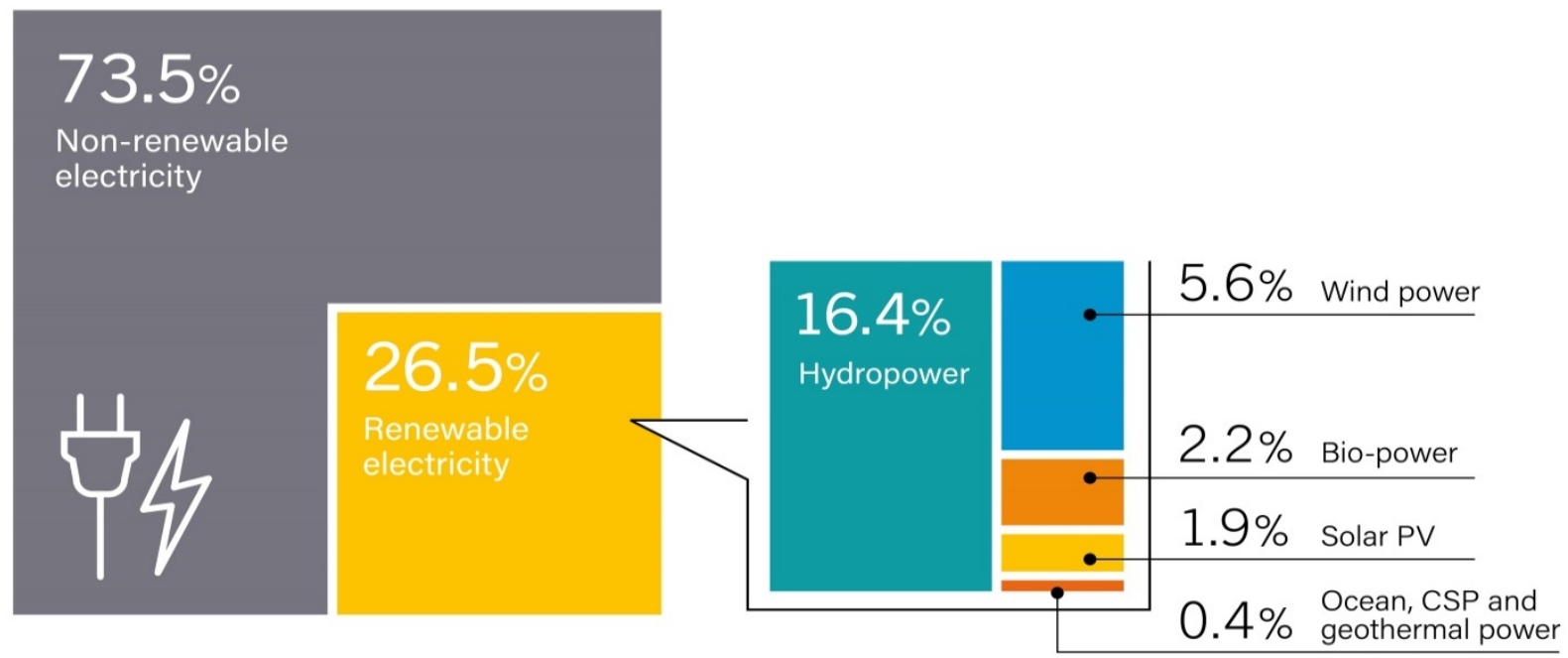

REN21

RENEWABLES 2018 global StATUS REPORT

Source: Renewables Global Status Report

Figure 3. Renewable Energy Share of Global Electricity Production 2017 


\section{Challenges and Current Results}

\subsection{Challenges}

The idea and the goals of the targeted and necessary energy turnaround are received very positively by the German population as a whole. Various surveys show that they are supported by a large majority across all age and education groups. A survey by the Institute for Transformative Sustainability Research (IASS) in 2017 confirms a high level of support for the phasing out of nuclear power generation and the phasing out of power generation from coal. Overall, $84 \%$ of the population agrees that renewable energies need to be supported. On the other hand, a large part of the population finds the implementation overly expensive and generally too unfair, because e.g. individuals are more heavily burdened than large commercial consumers (Fraunhofer IWES / IWP, 2012).

Ultimately, however, it has to be stated that there is a certain amount of double color among various people. Roughly speaking, this expresses itself according to the motto that one is generally in favor of something (for example the envisaged energy turnaround), but de facto does not want to pay for it separately, nor does it wish to pay any other detriment, for example, optical and other impairments by wind energy plants, would like to suffer. This attitude corresponds to behaviors that do not want to avert a potential threat, but prefer to deport it to others. This problem also explicitly concerns the expansion of renewable energies.

\subsection{Achieved Results or Obstacles in Detail}

The current market penetration of heat pumps must be described as absolutely inadequate for Germany and ultimately for the whole world. In Germany, about 84,000 units were sold in 2018 (about 1 million heat pumps are currently in operation in Germany), with the largest manufacturer reaching a maximum of 15,000 units per year. This means that there are no relevant lot size effects and thus unit cost degression as with mass products such. a refrigerator based on a similar principle, but produced millions of times a year. Due to this fact, a heat pump is ultimately not as cheap as it should be to find the interest of potential buyers in the necessary mass. This is accompanied by particularly intelligent controls according to the respective daily use, or even the interconnection of many heat pumps to network networks and use of smart grids. This would bring a further and significant cost reduction for the owner and / or operator. And ultimately the costs are decisive, whether one decides pro or con (Miara, VDI-Nachrichten, 2018).

Despite small fluctuations in the sales volume, the trend is obviously positive. Every year over 80,000 new heat pumps are installed in Germany (Bundesverband
Wärmepumpe). Even if the total amount and the trend are not yet groundbreaking, it can be said that "after all" so many are sold and then installed in the buildings. The number of heating oil heaters is still at around 5.5 million with a steady, slightly falling trend. Assuming the number of heat pumps sold would increase to 100,000 / year and the heating oil heaters would be replaced by the heat pumps, we would talk for a minimum of 55 years. In view of the anthropogenic climate change, an absolutely unacceptable time bracket. On the other hand, the heat pump manufacturers in Germany are facing rosy times from this point of view. They should still be working for years and decades.

A factual comparison also offers the British online service GreenMatch:

\begin{tabular}{|l|l|}
\hline \multicolumn{2}{|c|}{ Advantes and disadvantages of heat pumps } \\
\hline \multicolumn{1}{|c|}{ Advantages } & \multicolumn{1}{c|}{ Disadvantages } \\
\hline Lower running cost & High upfront cost \\
\hline Less maintenance & Fairly difficult to install \\
\hline $\begin{array}{l}\text { Safer than combustion-based } \\
\text { systems }\end{array}$ & Questionable sustainability \\
\hline Reduce your CO ${ }^{2}$ emissions & $\begin{array}{l}\text { Significant work to your house } \\
\text { and garden }\end{array}$ \\
\hline $\begin{array}{l}\text { Provides cooling during summers } \\
\text { Long life-span (+50 years), } \\
\text { sytremely reliable }\end{array}$ & $\begin{array}{l}\text { Not entirely carbon neutral, } \\
\text { electricity required }\end{array}$ \\
\hline $\begin{array}{l}\text { Renewable Heat Incentive (RHI) } \\
\text { scheme }\end{array}$ & Special planning permissions \\
\hline
\end{tabular}

Original source: GreenMatch

Figure 4. Advantages and Disadvantages by Heat Pumps, Developed by author

\subsection{State Support in the Selection of Heating Technologies}

Economic incentives are a crucial criterion for the introduction of climate protection measures. Thus, the German state offers financial support in the selection of new as well as in the replacement of existing heating techniques. Private and commercial investors are supported in implementing energy efficiency measures. The market incentive program has been anchored since 2009 in $\$ 13$ EEWärmeG (Act for the Promotion of Renewable Energies in the Heating Sector) (Bundesministerium für Wirtschaft und Energie, p. 69).

The promotional volume of the incentive program amounts to $€ 165$ million a year and can also be applied for using new heat pumps.

A newly introduced innovation support for model projects (the German state decides for itself what it considers eligible) completes the state-subsidized portfolio. These model projects are mainly low temperature heat networks, e.g. with large heat pumps lead to improved sector coupling and can also integrate accumulating waste heat. 
This value of an almost ridiculous 165 million (currently about 1.8\%) of state subsidies for the economy (iwd, 2018), would have to be massively increased (alternatively, the use of heating oil had to become massively and unilaterally more expensive), so that households much faster on climate-friendly technologies, such as Heat pumps, would change.

\subsection{Causes of Current Status Quo and the Lack of Enforcement on the World Market}

Here, and this is a profoundly bitter insight from a scientific point of view, it can only be speculated why this technology, especially in comparison to competitive energy sources such as sun or wind, has not prevailed comparably so far. Assuming that there are only five relevant influencing factors (1. available technology for the implementation / production of heat, 2. an almost infinite supply of the resource geothermal, 3. virtually no environmental pollution from production, transport and use, 4. political support for the Market Enforcement and 5. Costs), then it has to be stated that it can only be explained by the political enforcement or the related marketing of awareness among potential users. All relevant and purely factual arguments from technology, economy and environment, speak for the use of geothermal energy over the use of the heat pump.

\section{Conclusions}

German heat pump technology certainly has the potential to become the most important producer of heat in the context of the politically desired energy turnaround. The necessary technology is known, available and at least theoretically usable without problems. Geothermal energy is available virtually in infinite quantities worldwide, whether above or below ground. There are no capacity bottlenecks or other technological limits and the heat can usually be produced at the place of consumption, or at least in close proximity, so that any transport costs are minimized. Nevertheless, the geothermal energy and the market for heat pumps, which are necessary for the extraction and conversion, lead in Germany and to a large extent also worldwide, an absolute niche existence. There are only suboptimal explanations, such as that the state does not really support this technology, and that medium-sized heat pump manufacturers are not able to build a federation lobby that would be able to contribute to massive market penetration through related activities and the necessary budget. No doubt, here is still a billion market for those who are able to go through a lot size increase to a significant cost reduction per piece and also worldwide to market intensively. A field is only for Global Player.

\section{REFERENCES}

[1] Ast, M. (2012). Leitfaden zur Erdwärmenutzung in Niedersachsen. Landesamt für Bergbau, Energie und Geologie. Hannover (Germany).

[2] Bundesministerium für Wirtschaft und Energie: BWMI Broschüre Energieeffizienzstrategie Gebäude. Online, https://www.bmwi.de/Redaktion/DE/Publikationen/Energi e/energieeffizienzstrategie-gebaeude.pdf?_blob=publicati onFile\&v=25. Retrieved 26th August 2019.

[3] Bundesverband Geothermie, Home Page (no date). Häufig gestellte Fragen (FAQ). Online, https://www.geothermie.d e/geothermie/haeufig-gestellte-fragen-faq.html. Retrieved 14th April 2019.

[4] Bundesverband Wärmepumpe e.V., Home Page (no date). Absatzzahlen. Online, https://www.waermepumpe.de/press e/zahlen-daten/absatzzahlen/, and https://www.waermepu mpe.de/presse/pressemitteilungen/details/bwp-marktzahlen -2018-nachhaltiges-wachstum-mit-luft-nach-oben-deutlich es-signal-fuer-die-politik/\#content. Retrieved: 17th April 2019.

[5] Fraunhofer IWES/IBP (2017). Wärmewende 2030. Schlüsseltechnologien zur Erreichung der mittel- und langfristigen Klimaschutzziele im Gebäudesektor. Studie im Auftrag der Agora Energiewende. Herausgeber: Agora Energiewende, Kassel (Germany).

[6] Freeden, W. et al. (2018). Handbuch Oberflächennahe Geothermie. Springer Verlag Berlin, Heidelberg (Germany). DOI https://doi.org/10.1007/978-3-662-503072.

[7] Geothermal Communities (GEOCOM), Home Page (no date). Geothermal Systems and Technologies. 7. Geothermal Energy for power generation. Online, https://ge othermalcommunities.eu/assets/presentation/7.Course_GT. pdf. Retrieved 14th April 2019.

[8] GreenMatch, Home Page (2018). Heat Pumps: 7 Advantages and Disadvantages. Online, https://www.greenmatch.co.uk /blog/2014/08/heat-pumps-7-advantages-and-disadvantage s. Retrieved 16th April 2019.

[9] Iwd, Home Page (2018.02.27.). Subventionen - was der Staat am stärksten fördert. Online, https://www.iwd.de/arti $\mathrm{kel} /$ subventionen-was-der-staat-am-staerksten-foerdert-379 010/. Retrieved 22nd August 2019.

[10] Leipziger Institut für Energie GmbH (2012). Ökologische und ökonomische Optimierung des Wärmemarktes. Teilbericht B. Biogasrat e.V. (Berlin, Germany) Ibidem Verlag (Stuttgart (Germany). ISBN 978-3-8382-0355-3.

[11] Mechanical Engineering, Home Page (2016). Refrigeration \& Air Conditioning, Thermodynamics. Online, http://mech -engineeringbd.blogspot.com/2016/07/heat-pump.html. Retrieved 13th April 2019.

[12] Miara, M. (2018). Die Installation ist entscheidend. Online, https://www.vdi-nachrichten.com/Fokus/Die-Installation-e ntscheidend. Retrieved 16th April 2019. 
[13] Miara, M., et al. (2013). Wärmepumpen, Heinzen - Kühlen - Umweltenergie nutzen. Stuttgart, Fraunhofer IRB-Verlag. ISBN-13: 978-3816790464.

[14] RealClearEnergy, (2014). Geothermal now surpasses 10,000 MW Worldwide. Online, https://www.realclearenergy.org/ articles/2014/09/24/geothermal_now_surpasses_10000_m g_worldwide_108032.html. Retrieved 15th April 2019.

[15] Renewable Energy Policy Network (2018). Renewables 2018. Global Status Report. A comprehensive annual overview of the state of renewable energy. Online, http://www.ren21.net/status-of-renewables/global-status-re port/. Paris, France. Retrieved 14th April 2019.

[16] Richter, A. (2018). Top 10 Geothermal Countries based on installed capacity - Year End 2017. Online, http://www.thi nkgeoenergy.com/top-10-geothermal-countries-based-on-i nstalled-capacity-year-end-2017/. Retrieved 26th August 2019.

[17] Stober, I., Bucher, K. (2014). Geothermie. Springer Verlag Berlin, Heidelberg (Germany). DOI 10.1007/978-3-642-41 763-4.

[18] Tiator, I., Schenker, M. (2014). Wärmepumpen Wärmepumpenanlagen. Würzburg (Germany), Vogel Buchverlag. ISBN-13: 978-3802319112.

[19] U.S. Global Change Research Program (2018). Fourth National Climate Assessment. Volume II. Impacts, Risks and Adaption in the United States. Online:https://nca2018. globalchange.gov/\#sf-1. Retrieved 12th April 2019.

[20] Umweltbundesamt, Home Page (2019). Erneuerbare Energien in Zahlen. Online, https://www.umweltbundesam t.de/themen/klima-energie/erneuerbare-energien/erneuerba re-energien-in-zahlen\#waerme. Retrieved 10th April 2019. 